\title{
RISK AND REWARD OF INTERNATIONAL INVESTING FOR U.S. RETIREMENT SAVERS: HISTORICAL EVIDENCE
}

\author{
Gary Burtless* \\ CRR WP 2006-25 \\ Released: December 2006 \\ Draft Submitted: October 2006 \\ Center for Retirement Research at Boston College \\ 258 Hammond Street \\ Chestnut Hill, MA 02467 \\ Tel: 617-552-1762 Fax: 617-552-0191 \\ http://www.bc.edu/crr
}

* Gary Burtless is the John C. and Nancy D. Whitehead Chair in Economic Studies at the Brookings Institution. The research reported herein was performed pursuant to a grant from the U.S. Social Security Administration (SSA) funded as part of the Retirement Research Consortium. The findings and conclusions are solely those of the author and do not represent the views of SSA, any agency of the Federal Government, the Brookings Institution, or Boston College.

(C) 2006, by Gary Burtless. All rights reserved. Short sections of text, not to exceed two paragraphs, may be quoted without explicit permission provided that full credit, including ${ }^{C}$ notice, is given to the source. 


\section{About the Center for Retirement Research}

The Center for Retirement Research at Boston College, part of a consortium that includes parallel centers at the University of Michigan and the National Bureau of Economic Research, was established in 1998 through a grant from the Social Security Administration. The Center's mission is to produce first-class research and forge a strong link between the academic community and decision makers in the public and private sectors around an issue of critical importance to the nation's future. To achieve this mission, the Center sponsors a wide variety of research projects, transmits new findings to a broad audience, trains new scholars, and broadens access to valuable data sources.

\section{Center for Retirement Research at Boston College}

258 Hammond Street

Chestnut Hill, MA 02467

phone: 617-552-1762 fax: 617-552-0191

e-mail: crr@bc.edu

www.bc.edu/crr

Affiliated Institutions:

American Enterprise Institute

The Brookings Institution

Center for Strategic and International Studies

Massachusetts Institute of Technology

Syracuse University

Urban Institute 


\begin{abstract}
A crucial decision facing retirement savers is how to allocate their savings across broad investment classes, including the choice of how to divide investments between domestic and foreign holdings. This study investigates whether cross-border investing would have been advantageous to U.S. retirement savers in the past. The analysis is based on empirical evidence on asset returns in eight industrialized countries that have reliable historical time series data on stock and government bond returns. The goal is to determine whether U.S. workers would have obtained higher expected retirement incomes, with smaller risk of catastrophic investment shortfalls, if they invested part of their retirement savings in foreign stocks and bonds without hedging the currency risks of their overseas investments. The results show that workers could indeed have increased their expected pensions if they included unhedged foreign assets in their portfolio and if the portfolio were selected from one on the efficient frontier. Under many naïve investing strategies, however, increasing workers' allocation to overseas assets will not reduce the risk of catastrophically poor investment performance. The tabulations show that the risk of obtaining a very low pension replacement rate actually increases if workers allocate a sizeable percentage of their savings to overseas investments.
\end{abstract}




\section{Introduction}

A crucial decision facing retirement savers is how to allocate their savings across broad investment classes, including common stocks, bonds, real estate, and guaranteed income contracts. Savers must also decide how to divide investments between domestic and foreign holdings. This study focuses on the latter choice. Workers' allocation decisions across broad investment classes have been intensively studied, both from a theoretical perspective and using empirical evidence on actual worker choices (see Holden and VanDerhei 2004 and the citations listed therein). Analysts have only rarely examined the allocation of retirement savings across domestic and foreign holdings, however. Most academic analysts and many financial planners believe investors can obtain better returns with less risk by including foreign investments in their portfolios. This implies that with an optimal mix of foreign and domestic holdings, workers should expect higher annual returns, while the fluctuations in the value of their portfolios should be smaller than would be the case if all retirement savings were invested in domestic assets.

This study investigates whether cross-border investing would have been advantageous for retirement savers in the past. The analysis is based on empirical evidence on asset returns in a number of countries that have reliable historical time series data on investment returns. The goal is to determine whether workers would obtain higher expected retirement incomes, with smaller risk of catastrophic investment shortfalls, if they invested part of their retirement savings in foreign stocks and bonds. In addition, using retrospective data it is possible to see how varying the percentage of workers' savings held in foreign investments affects the risk and expected return of their retirement portfolios. Naturally, the optimal allocation to foreign assets may differ for workers who are located in different countries. The emphasis in this paper is on the risks and returns facing U.S. retirement savers. My assumption is that workers expect to retire in their home countries, so they will want to maximize the real consumption they can obtain after investments are converted into their home currencies.

The following sections examine evidence on the likely success of definedcontribution pensions in providing retirement incomes to typical workers. Historical and simulated data on financial market performance are used to evaluate the market risks 
facing contributors in a private system based on defined-contribution pension accounts. The paper provides evidence on these risks by considering the hypothetical pensions that workers in the United States would have received based on financial market performance between 1927 and 2005 if they had accumulated retirement savings in such accounts. The contributors to individual retirement accounts are assumed to have identical careers and to contribute a fixed percentage of their wages to private investment funds. When contributors reach retirement age, they convert their retirement savings into a level annuity. To make calculations that are comparable across time and across investment portfolios, all contributors are assumed to have an identical career path of earnings and to face the same mortality risks after reaching retirement. Contributors differ only with respect to the composition of their retirement portfolios, the level and timing of stock and bond returns, bond yields when they reach retirement, and price inflation. These differences occur because of the differing start and end dates of the workers' careers and because workers invest in different portfolios over the course of their careers.

\section{Risk and Return in Defined-Contribution Pension Plans}

The goal of a pension system is to replace labor earnings lost as a result of old age, premature death, or disability. Most rich countries achieve this goal through mandatory, publicly financed pensions. The typical public program is a defined-benefit

program in which the pension is calculated on the basis of the worker's years of coverage under the system and average covered wages while the worker is contributing to the system (World Bank 1994, esp. pp. 102-09). Benefits are largely financed out of current contributions of active workers and their employers.

Private retirement accounts, in contrast, are usually operated as funded programs. Many advocates of reform in public pensions believe that a new retirement system should be built around defined-contribution rather than defined-benefit pensions. The U.S. employer-sponsored pension system has already seen a major shift toward definedcontribution plans, which now cover two-thirds of the active participants and own more than $50 \%$ of the assets held by the private pension system (EBRI 2002). Instead of contributing to a collective, pay-as-you-go retirement program, workers in definedcontribution plans build up retirement savings in individually owned and directed private 
accounts. Workers can withdraw their funds from the accounts when they become disabled or reach the retirement age, and their heirs inherit any funds accumulated in the account if the worker dies before becoming disabled or reaching retirement age. At the time a worker chooses to start receiving a pension, some or all of the funds in the worker's account may be converted into an annuity that lasts until the worker dies. In most plans, workers are free to decide how their contributions are to be invested, at least within broad limits.

This paper focuses on workers' benefits and returns under a pure definedcontribution system rather than on benefits under the overall pension system, which includes Social Security A defined-contribution system allocates risks in a very different way than a collective, defined-benefit system. Under most public pension systems, workers born in the same year who have similar earnings records and have the same number of dependents receive similar retirement benefits. In contrast, workers participating in a defined-contribution system directly bear most or all of the risks associated with financial market fluctuations.

Workers enrolled in a defined-contribution pension plan face three kinds of financial market risk. They are exposed to the risk that the real return on their contributions will fall short of the historical average over the course of their working careers. If workers obtain unexpectedly low returns on their retirement savings, they will enter old age with little savings to pay for their retirement.

Second, at the point they retire workers may find it expensive to purchase annuities. Workers who want to ensure they will not outlive their assets will convert some or all of their retirement savings into an annuity around the time they retire. The market price they pay for annuities depends on four factors: their expected life span when they purchase annuities, the amount of adverse selection among the population buying annuities, the profit requirements needed to induce insurance companies to offer annuities, and the expected return on assets in which insurance companies will invest their reserves. Even assuming that mortality risk among workers of the same age is identical, that adverse selection among potential annuity buyers is negligible, and that insurance companies will sell annuities at zero profit, workers will still pay widely 
varying prices for annuities over time because of fluctuations in expected returns on insurance company reserves.

Finally, workers who buy nominal annuities are subject to inflation risk. Inflation that occurs after a worker retires can have a dramatic impact on the purchasing power of a pension.

One way to evaluate the risks just mentioned is to calculate the real pensions workers would have obtained if they had contributed to a defined-contribution plan in the past. To calculate such pensions it is necessary to define a standard career path of earnings and pension contributions, calculate the assets that would be accumulated under a chosen investment strategy, and estimate the real pension the worker could purchase with the assets accumulated at retirement. The calculations that follow are based on assumptions and a methodology I developed in past papers (Burtless 2003a and 2003b). Unlike the earlier papers, however, this one considers the impact on retirement consumption when some retirement savings are invested abroad. I assume all workers have a full, 40-year career that begins at age 22 and ends at 62. In the absence of economy-wide wage growth, workers are assumed to have a lifetime path of real earnings that matches the age-earnings profile of employed U.S. men in 1995 (U.S. Census Bureau 1996, p. 34). In 1995 the earnings of 22-year-old American males were roughly onefourth those of 45 -year-olds, while earnings of 60 -year-olds were $17 \%$ less than those of 45-year-olds. The career path of earnings is also affected by the growth of real wages in the wider economy, which for purposes of this exercise is assumed to be $1.5 \%$ a year, approximately the growth rate of U.S. real wages since World War II.

I calculate the value of savings at retirement using two main assumptions. Workers contribute to their pension plans on the first day of every year, and they follow a consistent investment strategy over their careers. In particular, workers are assumed to invest their retirement savings in some desired combination of standard assets - indexed stock and bond funds from a number of industrialized countries - according to a schedule that is determined at the beginning of their careers. This does not mean the portfolio allocation to each asset remains fixed over the worker's career. Many financial planners urge savers to reduce their allocation to risky assets, especially equity funds and foreign investments, as they approach retirement. Many mutual fund companies offer target- 
retirement-year funds that gradually shift assets out of equity funds and overseas investments and into bond funds and cash as investors approach the target retirement year. I assume, however, that this reallocation takes place according to a fixed schedule. Workers do not reallocate their investments in response to their actual experience of investment returns earlier in their careers.

All stock dividends during the year are reinvested in new stock purchases, and all bond interest payments are reinvested in a standard portfolio of long-term government bonds. If workers invest in a mixture of both stocks and bonds and purchase assets in a variety of countries, they re-balance their portfolios at the end of each year to maintain the preferred allocation of stocks and bonds and allocation across different countries. Note that the allocation may differ from the allocation at the beginning of the previous year if the worker has decided to invest in a life-cycle or target-retirement-year fund. The income flows from assets in the retirement savings account are assumed to be free of individual income taxes at the time they are reinvested. In previous papers I ignored fund management expenses in calculating workers' saving accumulation. However, investors or their agents must pay trading fees and commissions when buying and selling financial assets. Management fees are higher on funds invested abroad than they are on funds that are domestically invested. A low-cost mutual fund company, the Vanguard Group, charges an annual fee of $0.18 \%$ on funds invested in its major U.S. stock index fund. Money invested in its main U.S. government bond fund incurs an annual expense charge of $0.26 \%$, and money invested in its developed country equity index fund is assessed $0.29 \%$ per year. Vanguard does not offer a mutual fund that invests solely in foreign government bond funds. Among 9 highly rated mutual funds that specialize in overseas bond investments, the average annual management fee in 2005 was $0.66 \%$. When calculating the net earnings on a worker's investment portfolio, I subtract these fees from the gross estimated returns.

When workers attain age 62, I assume they convert their accumulations into a single-life annuity that is fixed in nominal terms. The annuity seller bases its price on the expected mortality experience of American males who reached age 65 in 1995, using mortality projections of the Social Security Actuary (Board of Trustees, OASDI, 2001). The Actuary’s projections take account of gradual improvements in mortality experience 
that Americans are expected to enjoy over the next several decades. I assume the insurance company does not charge a load factor to cover its profit requirements or possible adverse selection among people seeking to buy annuities. Thus, retiring workers are assumed to purchase fair annuities.

In determining the sales price of an annuity, the insurance company assumes it will be able to invest the worker's funds at the long-term U.S. government bond yield prevailing when the annuity is purchased. Since the annual annuity payment is fixed in nominal terms, the insurance company uses the nominal bond yield in this calculation. The insurance company does not adjust the nominal value of the annuity from year to year to reflect changes in the price level. Insurance companies in a few industrial countries can now offer indexed annuities, because they can purchase indexed government bonds. However, the historical experience with this kind of asset is too recent for us to calculate the price that would have been charged for real annuities in the past.

A common measure of the value of a pension is the replacement rate. The replacement rate is simply the worker's real annuity divided by his average real earnings near the end of his career. In this paper I measure final career earnings as the average real wage earned between ages 54 and 58, when American male lifetime earnings are at their peak. Figure 1 shows replacement rates of hypothetical U.S. workers who retired after 40 -year careers that ended on January $1^{\text {st }}$ of the years indicated along the horizontal axis. The workers are assumed to contribute $7 \%$ of their wages to the retirement savings account. The dark, upper line shows replacement rates in successive years for workers who invest in a portfolio of common stocks that earns the same gross return as the Standard and Poor's composite stock index. ${ }^{1}$ The middle line shows replacement rates

\footnotetext{
${ }^{1}$ Data on consumer price inflation and on total nominal returns for stock and bond investments were obtained from Global Financial Data in April 2006 (www.globalfindata.com). Data on nominal exchange rates, which will be used in the analysis below, were obtained from the same source. Bond returns are measured for investments in government bonds which have a remaining maturity of at least 7 years or, in a few countries (including the United States), a somewhat longer maturity. Global Financial Data supplies financial information to financial planners, pension funds, and investment companies. Where possible, I checked the data against alternative estimates of inflation and stock and bond returns. The information for the United States corresponds closely to inflation and return data independently derived in a previous paper (Burtless 2003a).
} 
for workers who invest in a portfolio consisting one-half of U.S. equities and one-half of long U.S. government bonds. The bottom line displays replacement rates obtained by workers who invest all of their retirement savings in long-maturity government bonds. Replacement rates are measured at age 62, when workers first retire. For example, the first point along the top line shows the replacement rate of a worker who entered employment in 1927, contributed $7 \%$ of his earnings to a retirement account invested in U.S. common stocks, and converted his retirement savings into a level annuity at the start of 1967.

For the 40 overlapping 40-year careers ending in 1967-2006, the average replacement rate based on a stock portfolio is almost $82 \%$, within the range recommended by financial planners as an income goal in retirement. However, the standard deviation of replacement rates is $26 \%$, implying that the range of income replacement provided by stock-invested retirement savings plans is quite large. A worker who receives the ninth decile replacement rate would receive a pension that initially replaces $119 \%$ of his peak earnings, whereas a worker who receives the first decile replacement rate would collect a pension that replaces about half of this amount, or just $61 \%$ of peak earnings. The range of replacement rates is reduced if workers steadily invest a higher percentage of their retirement savings in bonds. This strategy reduces the standard deviation of the replacement rate, but it also substantially cuts the expected pension. Thus, one of the main goals of investing in a less risky portfolio may not be achieved. For example, with a 50-50 allocation to stocks and bonds the first decile replacement rate falls to just $34 \%$. If the goal of a conservative investment strategy is to protect workers' pensions in very poor financial markets, the strategy of investing steadily in long government bonds offers poor protection against the risk of obtaining a small pension.

\section{Investing Abroad}

Investing in assets in addition to U.S. stocks and bonds should improve a worker's chances of earning a target rate of return. Depending on the risk and return characteristics of the overseas assets that are available to retirement savers, workers should be able to achieve a given rate of return with less risk than is possible when the 
retirement portfolio consists solely of domestic assets. I evaluate alternative international investment strategies using historical annual return data covering the period from 1927 through 2005, the longest span of time for which comparable return data are available for a large sample of countries. In addition to the United States, my sample of countries includes Australia, Canada, France, Germany, Italy, Japan, and the United Kingdom. Measured in U.S. dollars, the market capitalization of companies traded in the stock markets of these eight countries accounts for about $84 \%$ of total world stock market capitalization (http://www.djindexes.com/mdsidx/).

Table 1 shows average returns on stock and bond investments in these countries over the 1927-2005 period. For each asset the table shows five measures of the average return. The first two measures show the geometric mean return, first measured in foreign currency units and then in constant overseas prices. From the point of view of a U.S. retirement saver, however, the more relevant return is the real return measured in constant U.S. dollars, for this is the return that determines how much retirement consumption can ultimately be financed out of $\$ 1$ invested today. The real U.S. return on investments in the Japanese stock market will differ from that obtained by Japanese investors as a result of fluctuations in the real U.S.-Japanese exchange rate. From the point of view of home-country investors, the domestic stock market has offered the best stock market return in Australia followed by the United States, Canada, the United Kingdom, France, Germany, and Japan. The poorest home-country stock return was obtained by Italian investors. U.S. investors obtained stock market returns that corresponded roughly to those obtained by overseas home-country investors, though real U.S. returns on German stocks were poorer than those obtained by German investors and real returns on French and Italian stocks were somewhat higher.

Table 1 shows sizable differences in real returns across countries. One dollar invested in the Australian stock market in January 1927 would have yielded almost \$280 to an Australian investor who survived to January 2006, whereas one lira invested in the Italian stock market in 1927 would have produced only 10.6 lira for an Italian investor in 2006. Investors in all countries have experienced periods in which equity returns were persistently above- or below-average. The persistence of equity returns is especially notable in Japan. Japanese investors enjoyed an extraordinary 15\% annualized rate of 
return on equities between 1948 and 1989, but this outstanding performance was counterbalanced by -10\% annual returns between 1927 and 1947 and -3\% returns after 1989. Japanese investors have also obtained very poor long-term returns on their bond investments, though real returns improved substantially after the mid-1970s. Investors in the four English-speaking countries earned the highest returns on bond investments, primarily because their governments have not defaulted on the public debt as a result of high inflation or major currency reform. Much of the variability in French, German, Italian, and Japanese bond returns can be traced to high inflation and currency reform in the immediate post-war period, when outstanding government bonds lost most of their value.

Table 1 contains evidence for an equity premium in all eight countries. People who invested in home-country stocks obtained substantially higher returns than people who invested in home-country bonds. The equity premium ranged from a low of 3.1 percentage points in Canada to a high of 6.0 percentage points in Japan. Note that U.S. investors obtain the same equity premium on overseas investments as home-country investors in the same overseas market. However, exchange-rate fluctuations usually magnify the standard deviations of overseas returns. Bond returns have a smaller standard deviation than stock market returns from the perspective of all home-country investors. However, exchange-rate variability means that returns obtained on overseas bond investments often have a higher standard deviation than stock market returns in a saver's home country. From the perspective of U.S. investors, the standard deviation on investments in French, German, Italian, and Japanese government bonds is greater than that on stock market investments in the United States, Australia, or Canada. For many investors, this combination of low expected returns and high risk will make overseas bond investments unattractive.

If American workers decide to invest some of their retirement savings in overseas assets, they must choose how to allocate their savings across foreign stocks and bonds and across investments in seven foreign countries. One solution to this problem is to allocate investments in proportion to the relative size of each asset class. This solution has been partially adopted by Vanguard in its design of target-retirement-year mutual funds. The funds hold three index portfolios, a total U.S. equity index fund, a total world 
stock market index fund (which excludes Canadian and U.S. equities), and a total U.S. bond market index fund. Thus, within each broad asset class the fund holds marketable securities in proportion to their importance in that asset class. However, Vanguard's target-year mutual funds do not hold positions in the three asset classes in proportion to their importance in global markets. For example, the market capitalization of U.S. equities represents slightly more than half of world equity capitalization, but U.S. stocks account for $80 \%$ of the equity holdings in the target-year portfolios (see Table 2). Vanguard's target-year funds do not hold any overseas bonds, nor do they hold cash. When workers are within 25 years of their target retirement age, Vanguard's fund managers reduce investors’ allocation to equities by about 1.5 percentage points a year and increase their allocation to U.S. bonds by the same amount. T. Rowe Price designs its basic allocation similarly, though only a small proportion of money is invested in index funds and a much larger proportion is invested in cash, especially as workers near retirement age. Interestingly, the T. Rowe Price target-year portfolio not only reduces savers' exposure to equities as they grow older, it also reduces the percentage of equity holdings invested overseas.

The paucity of historical data on global stock market capitalization makes it impossible to replicate reliably the long-term performance of Vanguard's target-year investment allocation. It is possible, however, to simulate the performance of a similar life-cycle investment strategy. Using information on national stock market capitalization supplied by Dow Jones indexes (www.djindexes.com/mdsidx/), I calculated the relative size of each overseas stock market over a recent span of years. On average, the most important stock market outside the United States was Japan's, which accounted for 42\% of equity holdings (measured in U.S. dollars) outside the U.S during the period from 1992 through 2005. In descending order, the other countries were the United Kingdom (25\%), France (10\%), Germany (9\%), Canada (7\%), Italy (4\%), and Australia (4\%). ${ }^{2}$ In

\footnotetext{
${ }^{2}$ These weightings differ somewhat from estimates by Global Financial Data covering a longer period. Global Financial Data's estimates cover a period that extends back to 1979 but ends in 2002. A notable difference between the two sets of estimates is the larger weighting of Japanese stocks and smaller weighting of U.K. stocks in a period that includes the boom in Japanese stock market prices during the 1980s. In 1987 Japanese equities were worth more than U.S. equities, and their market value accounted for $69 \%$ of the value of all non-U.S. equity
} 
allocating workers' foreign equity holdings across the seven countries, I assume that workers rebalance their foreign equity holdings each year to maintain these weightings. Using currently available information I am unable to simulate the effects of changing the country weights to reflect stock market capitalization on the last trading day of the year.

My data on exchange rates, inflation, and market returns cover the period from 1927 through 2005. The observation period contains a total of 79 years, so it is straightforward to predict the pensions of 40 workers, namely, those who start their working careers at the beginning of successive years from 1927 to 1966 and begin their retirements between 1967 and 2006. The pensions of these workers do not fairly reflect all the evidence on returns between 1927 and 2005, however, because annual returns at the beginning and the end of the 79-year period are reflected in the pensions of only one or two workers whereas returns in the middle of the 79 years are reflected in the pensions of essentially all of the simulated workers. To give equal weight to each annual observed return, I created a sequence of annual returns so that each of the 79 annual observations is used an equal number of times. ${ }^{3}$

The distribution of pension replacement rates from three investment strategies is displayed in Figure 2. The first investment strategy is the life-cycle asset allocation plan embodied in Vanguard's target-retirement-year funds. Under this strategy, 90\% of workers' retirement savings are invested in equities until they are 25 years from retirement. At that point, the allocation to equities gradually declines up through the target retirement age. Foreign equities comprise $20 \%$ of total equity holdings at every age. The remainder of the portfolio consists of U.S. government bonds, rather than all marketable bonds as in the Vanguard target-year fund. For comparison, Figure 2 also shows the expected distribution of replacement rates under two strategies in which savings are invested solely in U.S. assets, either entirely in U.S. equities or $50 \%$ in

holdings in the sample countries. I do not currently have data on some countries' stock market capitalization in years before 1979 .

${ }^{3}$ In essence, observations are created for the years 2006-2044 based on observed returns for 1927-1966. Each annual observation of market returns between 1927-2005 is thus used exactly 40 times, once to reflect returns in the first year of a worker's career, once to reflect returns in the second year, and so on up through the last year of a 40-year career. An alternative approach is to predict pensions using Monte Carlo simulation, but this would require specification of the full 
equities and 50\% in long-duration government bonds. The Vanguard life-cycle portfolio achieves better results than the 50-50 U.S. stock-bond portfolio, but worse results than a retirement savings plan where all pension contributions are placed in U.S. equities. The advantage of investing solely in U.S. equities is particularly large for workers who obtain above-average replacement rates. Workers who obtain the $90^{\text {th }}$-percentile replacement rate receive a pension that is $119 \%$ of their final pay if they invested solely in U.S. equities versus only 78\% if they invested in the Vanguard life-cycle portfolio. Interestingly, the more diversified portfolio does not yield any pension improvement for workers who obtain very poor replacement rates. At the $10^{\text {th }}$ percentile, the replacement rate under Vanguard's life-cycle allocation strategy is only $37 \%$ versus $41 \%$ under the plan that places all retirement savings in U.S. equities.

The results in Figure 2 do not provide a clear test of the advantages of overseas investments for reducing the risk or increasing the expected returns of a worker's retirement savings. Some of the poor performance of the life-cycle portfolio is caused by its comparatively heavy weighting of investments in the U.S. bond market rather than by poor or variable returns on its overseas equity holdings. To see this, consider the distribution of replacement rates under alternative portfolio allocation strategies when all retirement savings are invested in equities. Figure 3 shows the distribution of replacement rates when workers place $0 \%, 50 \%$, and $100 \%$ of their equity investments in overseas stock markets. ${ }^{4}$ Because the distribution of replacement rates is very skewed, it is helpful to divide the distribution between workers obtaining below-median pensions, on the left, and above-median pensions, on the right. On average, workers who allocate part of their equity investments to foreign holdings do better than workers who hold all their savings in U.S. markets. The average replacement rate for workers who invest solely in U.S. equities is $77 \%$; the average for workers who allocate half their savings to foreign equity holdings is $105 \%$; and the average for workers who allocate all their

time series correlation structure of stock and bond returns, a task that is beyond the scope of this paper.

${ }^{4}$ These calculations are performed under the assumption that the target weight of each foreign country in the overseas equity allocation is proportional to its GDP weight between 1980 and 2005. This assumption produces very similar results to those obtained when the target weight is proportional to the relative size of each country's stock market capitalization. 
savings to foreign equities is $126 \%$, almost 50 percentage points above the replacement rate when all equity holdings are invested in the United States. Note, however, that workers who obtain the lowest returns fare very poorly under the $100 \%$-foreign-equities strategy, and they do not fare very well under the 50\%-foreign stock / 50\% U.S. stock strategy. Even though the variability of replacement rates under a purely domestic equity investment strategy is high, the variability of rates under a mixed domestic-foreign portfolio is even higher.

This conclusion is strengthened by considering how workers’ expected replacement rates vary when the allocation to overseas equity investments increases. Holding constant the proportional allocation of investments in seven overseas markets, Figure 4 shows how replacement rates vary when the overall allocation to foreign equities rises. ${ }^{5}$ The allocation to foreign stocks is indicated on the horizontal axis. From top to bottom, the four lines in the figure show how the average replacement rate, the median replacement rate, the $10^{\text {th }}$ percentile replacement rate, and the $5^{\text {th }}$ percentile replacement rate vary as the allocation to foreign stocks increases. All of these indicators suggest U.S. workers can achieve gains from allocating part of their retirement savings to overseas equities, but the gains differ depending on which indicator is most important to the retirement saver. Workers who want to maximize their expected pensions should allocate all their savings to foreign holdings. However, these workers expose themselves to the risk of obtaining exceptionally small pensions if exchange-rate fluctuations and overseas returns are unfavorable. Workers who want to obtain the best median pension and the highest $10^{\text {th }}$ percentile pension will allocate about half their savings to overseas equities. Workers wishing to maximize the $5^{\text {th }}$ percentile pension will allocate about onethird of their savings to overseas investments. Note that the gain from shifting assets into overseas investments is relatively small for workers who are most concerned with protecting themselves against very poor retirement incomes. The gains are proportionately much larger for workers who focus on obtaining higher expected pensions.

\footnotetext{
${ }^{5}$ I assume the target weight of each foreign country in the overseas equity allocation is proportional to its GDP weight between 1980 and 2005.
} 
The evidence in Figures 3 and 4 is suggestive. U.S. retirement savers can obtain better average investment returns if they allocate some of their savings to overseas equity investments. But under naïve investing strategies they face a greater risk of facing catastrophic investment shortfalls than when all their retirement savings is invested domestically. This may help account for the relatively modest share of overseas investments in U.S. households’ portfolios (French and Poterba 1991; Cambell and Kräussl 2005).

\section{Optimizing the Savings Portfolio}

A large theoretical and empirical research literature has grown up around the issue of optimal portfolio allocation. The classical literature on asset allocation mainly deals with the problem of portfolio design when investors are making a single-period allocation and are well armed with information on the expected returns and the variance and covariance of returns for potential assets that can be included in their portfolios (Markowitz 1952; Sharpe 1964). The retirement saver's investment problem is more complicated, because it requires investors to decide on a portfolio allocation strategy that will extend across forty or more years. At the same time, it is not obvious whether the historical data on nominal and real returns provide a reliable guide to estimating either the expected returns or the variance-covariance structure of returns of different international assets. As noted above, U.S. investors in French, German, Italian, and Japanese stocks and bonds obtained terrible returns on investments made before 1948, but returns since the 1940s have been much better. In calculating a saver's optimal portfolio allocation, it might seem reasonable to disregard all return data from 1948 and earlier years. On the other hand, if there is mean reversion in stock market prices, part of the return earned on overseas equities after 1948 may simply reflect mean-reverting stock-price gains, and these should be discounted when translating 1949-2005 historical returns into an estimate of expected future returns.

A straightforward solution to the one-period allocation problem, as noted by Canner et al. (1997) and many other writers, is for savers to hold just two assets: a safe asset, such as Treasury bills, and a single mutual fund which in turn holds all risky assets in proportion to their observed market weights. Risk averse investors should allocate 
more of their portfolios to the safe asset; risk-tolerant investors should allocate more of their portfolios to the risky mutual fund. So far as I know, however, investment firms do not offer a mutual fund that includes all marketable risky assets or even those risky assets that are available in U.S. markets.

Rather than try to calculate the historical returns of such a fund, I instead calculate the returns on diversified international portfolios that are located on the efficient frontier. An efficient portfolio represents an allocation across risky assets that offers investors the highest return for a given level of risk or, equivalently, offers the lowest risk for a given level of expected return. Markowitz (1952) first described the efficient frontier as the set of efficient portfolios. Using 1927-2005 information on the annual real returns of the eight countries' stock fund indexes and bond fund indexes, I used standard optimization techniques to find efficient portfolios that offered a variety of levels of risk and expected return. Figure 5 shows the performance of two such portfolios. Both portfolios include equities from all eight countries but bond investments from only two - the United Kingdom and the United States. ${ }^{6}$ One of the efficient portfolios, "International Portfolio \#1,” was chosen to produce a combination of relatively low investment risk and low expected returns. The portfolio consists of 30\% bond investments and $70 \%$ stock investments. The second portfolio, “International Portfolio \#2,” allocates 94\% of retirement savings to equities. It offers higher expected returns but has a higher associated annual deviation in pension payouts. ${ }^{7}$ Unlike the international portfolios examined in Figures 2 - 4, the two international portfolios examined in Figure 5 are reasonably successful in avoiding very low pension payouts. Only at the very bottom of the payout distribution are pensions larger for U.S. workers who invest all their

\footnotetext{
${ }^{6}$ Efficient portfolios containing positive allocations to all eight bond funds and all eight equity funds produced smaller pensions for workers who received low replacement rates. To avoid this result, I constrained the allocation to bonds to be $0 \%$ for all countries except Britain and the United States. This constraint had little practical effect on the locus of the efficient frontier.

${ }^{7}$ Portfolio \#1 allocates the following percentage of funds to equity investments: $25 \%$ to Australian, $11 \%$ to Canadian, 3\% to French, $4 \%$ to German, $1 \%$ to Italian, $7 \%$ to Japanese, $2 \%$ to UK, and $19 \%$ to US stocks. In addition, $14 \%$ of funds are allocated to UK bonds and $16 \%$ to US bonds. Portfolio \#2 allocates higher percentages to equity holdings: 18\% to Australian, 19\% to Canadian, $12 \%$ to French, $6 \%$ to German, $1 \%$ to Italian, $11 \%$ to Japanese, $8 \%$ to UK, and $19 \%$ to US stocks. Just $6 \%$ of assets are allocated to UK bonds, and only $2 \%$ are allocated to US bonds.
} 
retirement savings in the U.S. stock market. The riskier international portfolio produces better pensions than the U.S.-only portfolio for nearly all workers. The advantage of this portfolio is particularly large for workers who obtain the median pension. The median replacement rate for workers who invest solely in U.S. equities is 20 percentage points lower than the median rate for workers who invest in the riskier international portfolio. The lower-risk international portfolio is less successful in producing good pensions, especially for workers who receive above-median pension payouts. From the point of view of retirement savers, the less risky international portfolio offers lower variability in payouts than either of the other two portfolios. However, it also offers a substantially lower average payout, and it does no better than the other two portfolios in protecting workers against the risk of a very small pension.

\section{Discussion}

The analysis in this paper provides some indication of the potential gains workers can achieve from portfolio diversification that includes overseas stocks and bonds. In theory the availability of these investments should increase workers' expected returns holding constant their investment risks. The results show that workers can substantially increase their expected pensions if they include foreign equities in their pension portfolios. Under many naïve investing strategies, however, increasing workers’ allocation to overseas assets will not reduce the risk of catastrophically poor investment performance. In fact, my tabulations show that the risk of obtaining a very low pension replacement rate actually increases if workers allocate a sizeable part of their savings to overseas investments. One reason is that historical returns in most overseas markets have been lower than those in the United States. Another is that currency appreciation can erode the returns U.S. investors obtain on their overseas holdings. Finally, some foreign markets, including very large ones, have experienced lengthy periods in which returns are persistently low or even negative. If workers should retire when the dollar is sharply appreciating or when overseas markets are in a persistent slump, workers' returns on their overseas holdings will be low.

Using standard optimization methods, I was able to devise internationally diversified allocations that offered workers some protection against ruinous investment 
performance. One of these portfolios also offered workers better expected returns with lower risks than they could have obtained from U.S. equity investments. This finding should be treated with caution, however. First, the efficient portfolios were selected based on knowledge about actual returns and the variance and covariance of returns over the simulation period. It is reasonably certain that these indicators of past financial market performance do not provide a reliable guide to future returns. Second, it is notorious that portfolio optimization when there is a large number of assets produces a large number of candidate portfolios along the efficient frontier. Small errors in measuring expected returns or the covariance structure of returns can produce major errors in the composition of apparently efficient portfolios. Moreover, two efficient portfolios with apparently similar risk and expected return characteristics may produce dramatically different results if maintained over 40 years of active work life.

Even though workers on average can obtain good pensions under a defined contribution system, this kind of pension generates wide variability in outcomes, even for workers who follow an identical investment strategy. It is not obvious from this analysis that workers are less likely to experience ruinous investment returns if their pension portfolios include overseas assets. Assuming U.S. workers deposit 7\% of their annual pay into a retirement account that is invested in an "optimal” portfolio of foreign and domestic equities and bonds, recent experience suggests their initial pensions could range from a low of $51 \%$ of their peak career earnings up to more than $115 \%$ of peak earnings. These are the actual replacement rates 62-year-old workers would have obtained in 2000 and 2003 if their careers and contribution patterns matched the assumptions of this paper and their investment strategy matched the riskier international portfolio described in the previous section. An important question in thinking about the role of definedcontribution pensions is whether this kind of pension variability is acceptable to most workers. 


\section{References}

Brown, Jeffrey R., Olivia S. Mitchell, and James M. Poterba. 2002. “The Role of Real Annuities and Indexed Bonds in an Individual Accounts Retirement Program,” in J.R. Brown, O.S. Mitchell, J.M. Poterba, and M.J. Warshawsky, eds., The Role of Annuity Markets in Financing Retirement (Cambridge: MIT Press), pp. 107-52.

Burtless, Gary. 2003a. "Social Security Privatization and Financial Market Risk: Lessons from U.S. Financial History,” T. Ihori and T. Tachibanaki, eds., Social Security Reform in Advanced Countries (London and New York: Routledge). . 2003b. "What Do We Know About the Risk of Individual Account Pensions? Evidence from Industrial Countries,” American Economic Review 93(2) May, pp. 354-59.

Campbell, Rachel A., and Roman Kräussl. 2005. "Revisiting the Home Bias Puzzle: Downside Equity Risk.” Working Paper. (Maastricht: Maastricht University, Faculty of Economics and Business Administration).

Canner, Niko, N. Gregory Mankiw, and David Weil. 1997. “An Asset Allocation Puzzle,” American Economic Review 87(1) March, pp. 181-191.

Employee Benefit Research Institute (EBRI). 2002. An Evolving Pension System: Trends in Defined Benefit and Defined Contribution Plans, EBRI Issue Brief No. 249 (Washington: EBRI).

French, Kenneth R., and James M. Poterba. 1991.“Investor Diversification and International Equity Markets.” American Economic Review, 81 (2) May, pp. 222226.

Holden, Sarah, and Jack VanDerhei. 2004. “401(k) Plan Asset Allocation, Account Balances, and Loan Activity in 2003.” Perspective 10(2). Washington, DC: Investment Company Institute.

Markowitz, Harry M. 1952. “Portfolio Selection,” Journal of Finance, 7 (1), pp. 77-91.

Sharpe, William F. 1964. "Capital Asset Prices: A Theory of Market Equilibrium under Conditions of Risk,” Journal of Finance, 19(3), pp. 425-442.

U.S. Census Bureau. 1996. Money Income in the United States: 1995, Series P60-193 (Washington: U.S. Government Printing Office).

World Bank. 1994. Averting the Old Age Crisis (Oxford and New York: Oxford University Press). 
Table 1. Nominal and Real Returns Measured in Foreign Currency Units and U.S. Dollars, 1927-2005

Percentage points

\begin{tabular}{|c|c|c|c|c|c|c|c|c|}
\hline & Australia & Canada & France & Germany & Italy & Japan & U.K. & U.S.A. \\
\hline \multicolumn{9}{|l|}{ Stock returns (composite equity index) } \\
\hline \multicolumn{9}{|l|}{ Geometric returns } \\
\hline Nominal returns, foreign currency units & 12.2 & 10.1 & 12.8 & 6.9 & 12.8 & 12.8 & 10.9 & 10.2 \\
\hline Real returns, foreign consumption units & 7.4 & 6.7 & 4.7 & 4.5 & 3.0 & 3.8 & 6.2 & 6.9 \\
\hline Returns in constant U.S. dollars & 7.2 & 6.6 & 5.2 & 1.9 & 3.7 & 3.9 & 6.2 & 6.9 \\
\hline \multicolumn{9}{|l|}{ Arithmetic returns } \\
\hline Returns in constant U.S. dollars & 9.4 & 8.6 & 10.1 & 15.2 & 8.2 & 10.9 & 9.0 & 8.9 \\
\hline Standard deviation of returns, constant U.S. dollars & 22.6 & 21.2 & 35.2 & 87.9 & 34.0 & 35.4 & 25.5 & 20.4 \\
\hline \multicolumn{9}{|l|}{ Bond returns (long government bonds) } \\
\hline \multicolumn{9}{|l|}{ Geometric returns } \\
\hline Nominal returns, foreign currency units & 7.4 & 6.9 & 7.0 & 3.5 & 8.3 & 6.3 & 7.3 & 5.3 \\
\hline Real returns, foreign consumption units & 2.9 & 3.6 & -0.7 & 1.2 & -1.1 & -2.2 & 2.8 & 2.1 \\
\hline Returns in constant U.S. dollars & 2.6 & 3.5 & -0.2 & -1.3 & -0.5 & -2.1 & 2.7 & 2.1 \\
\hline \multicolumn{9}{|l|}{ Arithmetic returns } \\
\hline Returns in constant U.S. dollars & 3.9 & 4.1 & 3.8 & 5.4 & 2.8 & 2.8 & 3.8 & 2.5 \\
\hline Standard deviation of returns, constant U.S. dollars & 18.1 & 12.0 & 23.6 & 40.1 & 24.8 & 24.3 & 15.7 & 9.4 \\
\hline
\end{tabular}

Source: Author's tabulations of annual composite stock and bond return data from eight industrial countries, 1927-2005, as explained in the text. Data supplied by Global Financial Data (http://www.globalfinancialdata.com). The tabulations show gross returns; they ignore trading fees and management costs. 
Table 2. Portfolio Allocation across Investment Classes in TargetRetirement-Year Mutal Funds, 2006

\begin{tabular}{|c|c|c|c|c|c|c|}
\hline \multirow[b]{2}{*}{$\begin{array}{c}\text { Target Year of } \\
\text { Fund } \\
\end{array}$} & \multirow[b]{2}{*}{$\begin{array}{c}\text { Years to } \\
\text { Retirment }\end{array}$} & \multicolumn{5}{|c|}{ Percent of portfolio } \\
\hline & & U.S. Stocks & $\begin{array}{c}\text { Foreign } \\
\text { Stocks }\end{array}$ & $\begin{array}{c}\text { Total } \\
\text { Equities }\end{array}$ & U.S. Bonds & Cash \\
\hline \multicolumn{7}{|c|}{ Vanguard Target Retirement Year Portfolios, June 30, 2006} \\
\hline 2045 & 40 & 72 & 18 & 90 & 10 & 0 \\
\hline 2035 & 30 & 72 & 18 & 90 & 10 & 0 \\
\hline 2025 & 20 & 65 & 17 & 81 & 19 & 0 \\
\hline 2015 & 10 & 52 & 14 & 66 & 34 & 0 \\
\hline 2005 & 0 & 38 & 10 & 47 & 52 & 1 \\
\hline \multicolumn{7}{|c|}{ T. Rowe Price Target Retirement Year Portfolios, March 31, 2006} \\
\hline 2045 & 40 & 68 & 21 & 90 & 6 & 4 \\
\hline 2035 & 30 & 68 & 22 & 90 & 6 & 4 \\
\hline 2025 & 20 & 63 & 19 & 82 & 14 & 4 \\
\hline 2015 & 10 & 55 & 15 & 70 & 22 & 8 \\
\hline 2005 & 0 & 47 & 10 & 57 & 30 & 13 \\
\hline
\end{tabular}

Source: www.vanguard.com, downloaded August 1, 2006; and www3.troweprice.com, downloaded August 1, 2006. 
Figure 1. Replacement Rates of Full-Career U.S. Workers after Steady Investment in Alternative Portfolios Invested Domestically, 1927-2005

\section{Pension replacement rate: Alternative U.S. portfolios}

(\% of final earnings)

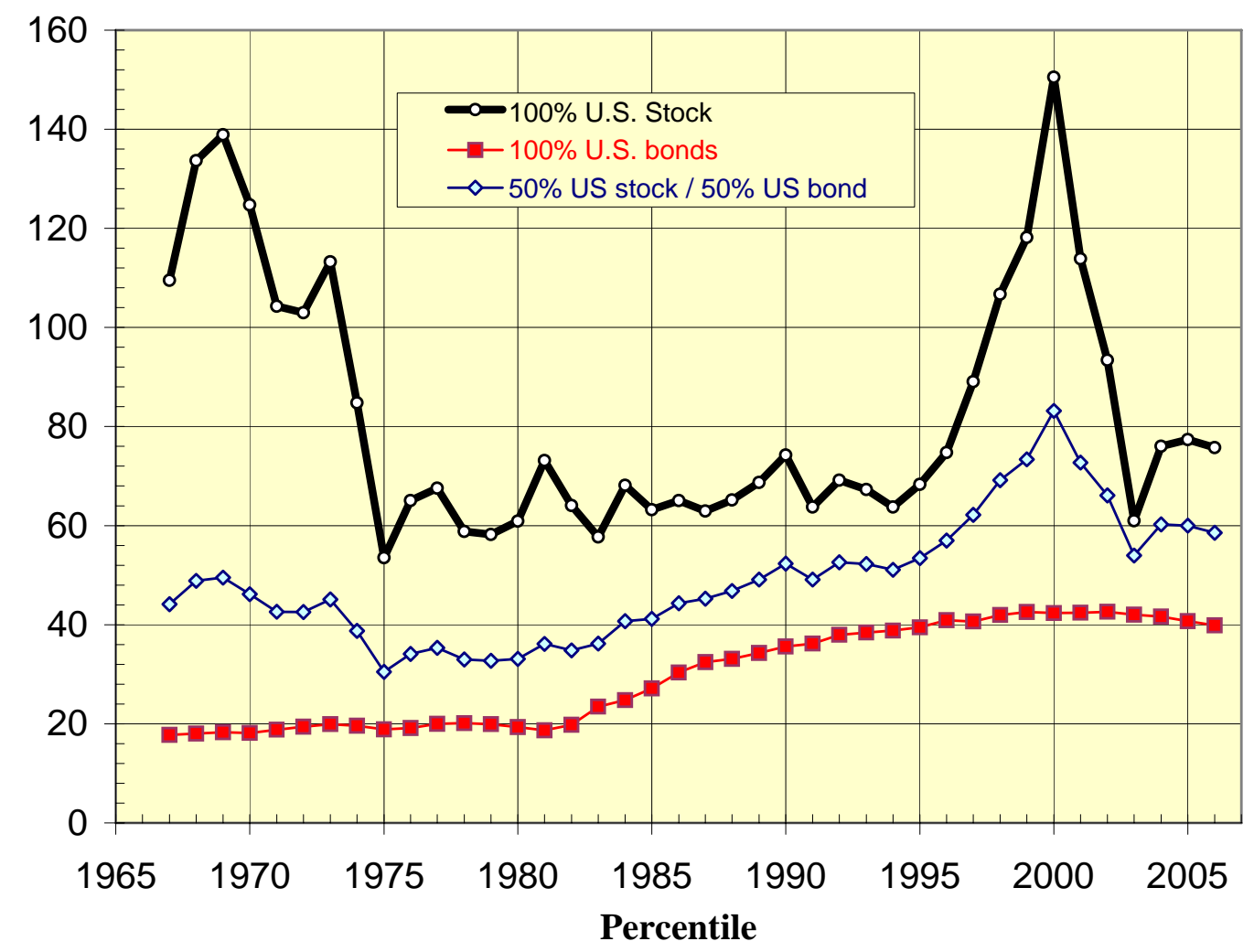

Source: Author's tabulations of annual composite U.S. stock and bond return data, 1927-2005, as explained in the text. Data supplied by Global Financial Data (http://www.globalfinancialdata.com). 
Figure 2. Distribution of Replacement Rates of Full-Career U.S. Workers under Three Retirement Investment Strategies, 1927-2005

\section{Pension replacement rate: Alternative U.S. portfolios}

(\% of final earnings)

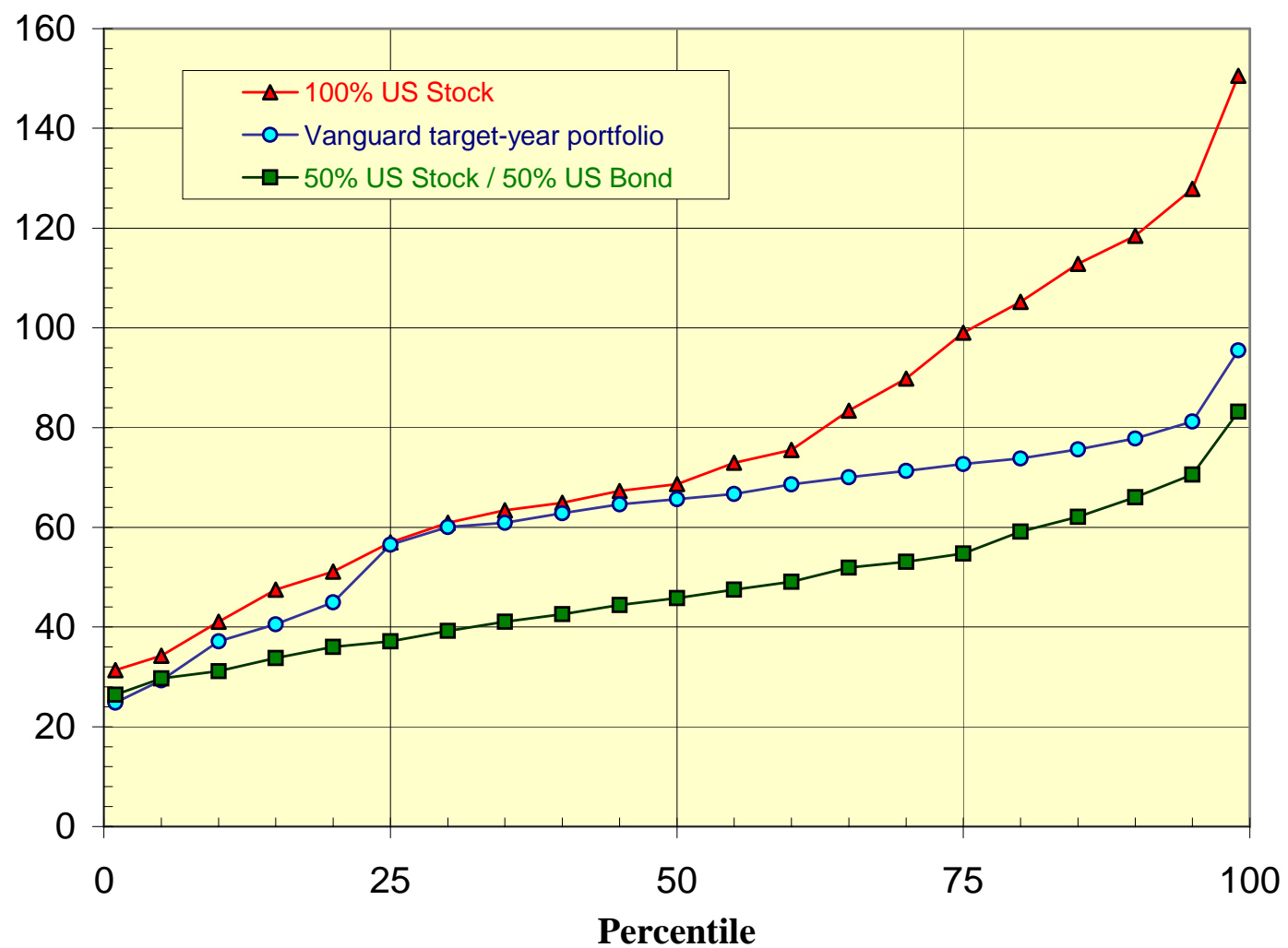

Source: Author's tabulations of annual composite stock and bond return data for eight industrial countries, 1927-2005, as explained in the text. Data supplied by Global Financial Data (http://www.globalfinancialdata.com). 
Figure 3. Distribution of Replacement Rates for Full-Career U.S. Workers after Steady Investment in Alternative Equity Portfolios Allocated across Eight Industrial Countries, 1927-2005
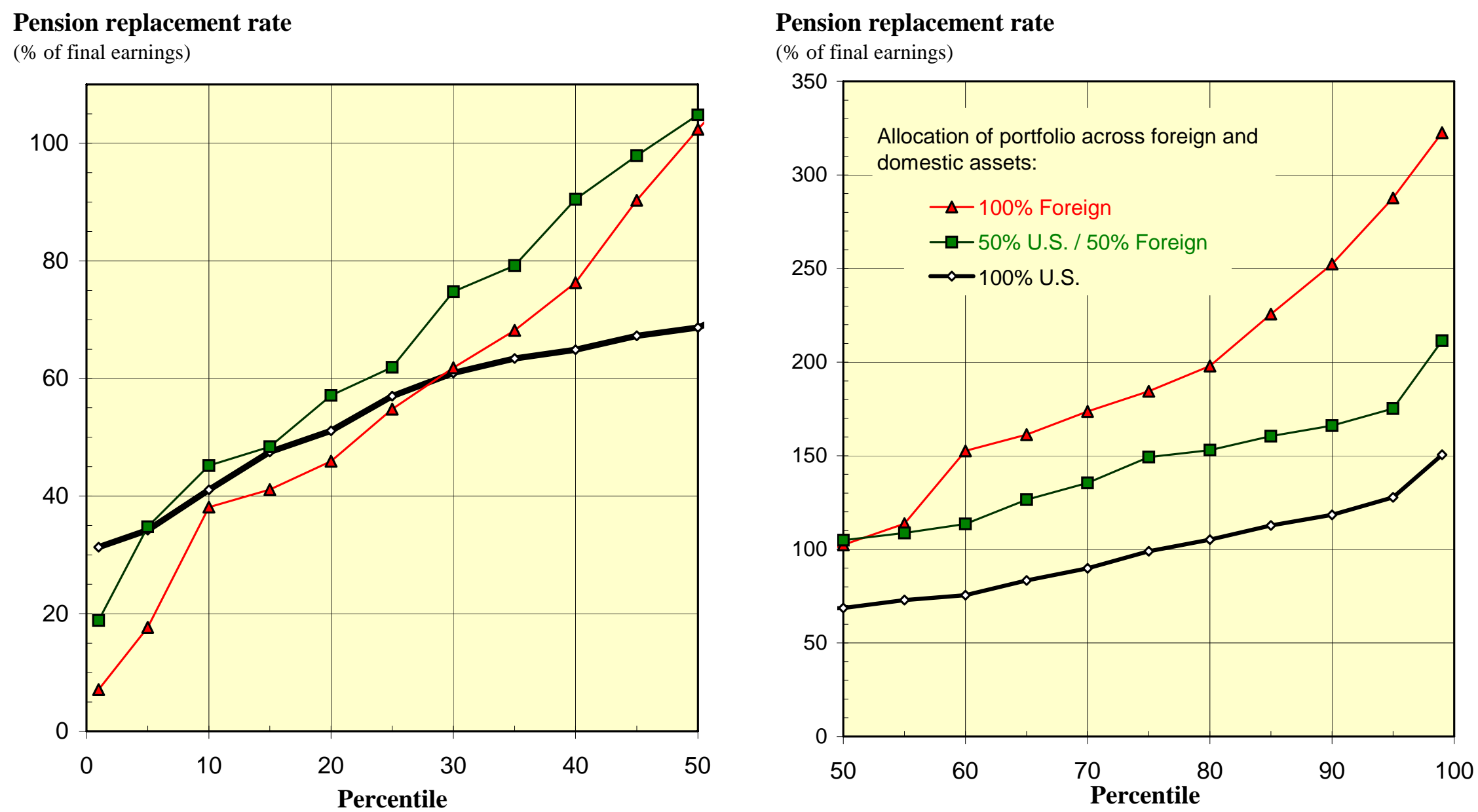

Source: Author's tabulations based on annual composite stock and bond return data from eight industrial countries, 1927-2005, as explained in the text. Allocation to each foreign country's asset is determined by its relative GDP weight in 1980-2005. Return and foreign exchange data supplied by Global Financial Data (http://www.globalfinancialdata.com); GDP data from IMF "World Economic Outlook" data base, May 2006. 
Figure 4. Selected Replacement Rates of U.S. Workers as a Function of Worker's Allocation to Foreign Stocks, 1927-2005

\section{Pension replacement rate}

(\% of final earnings)

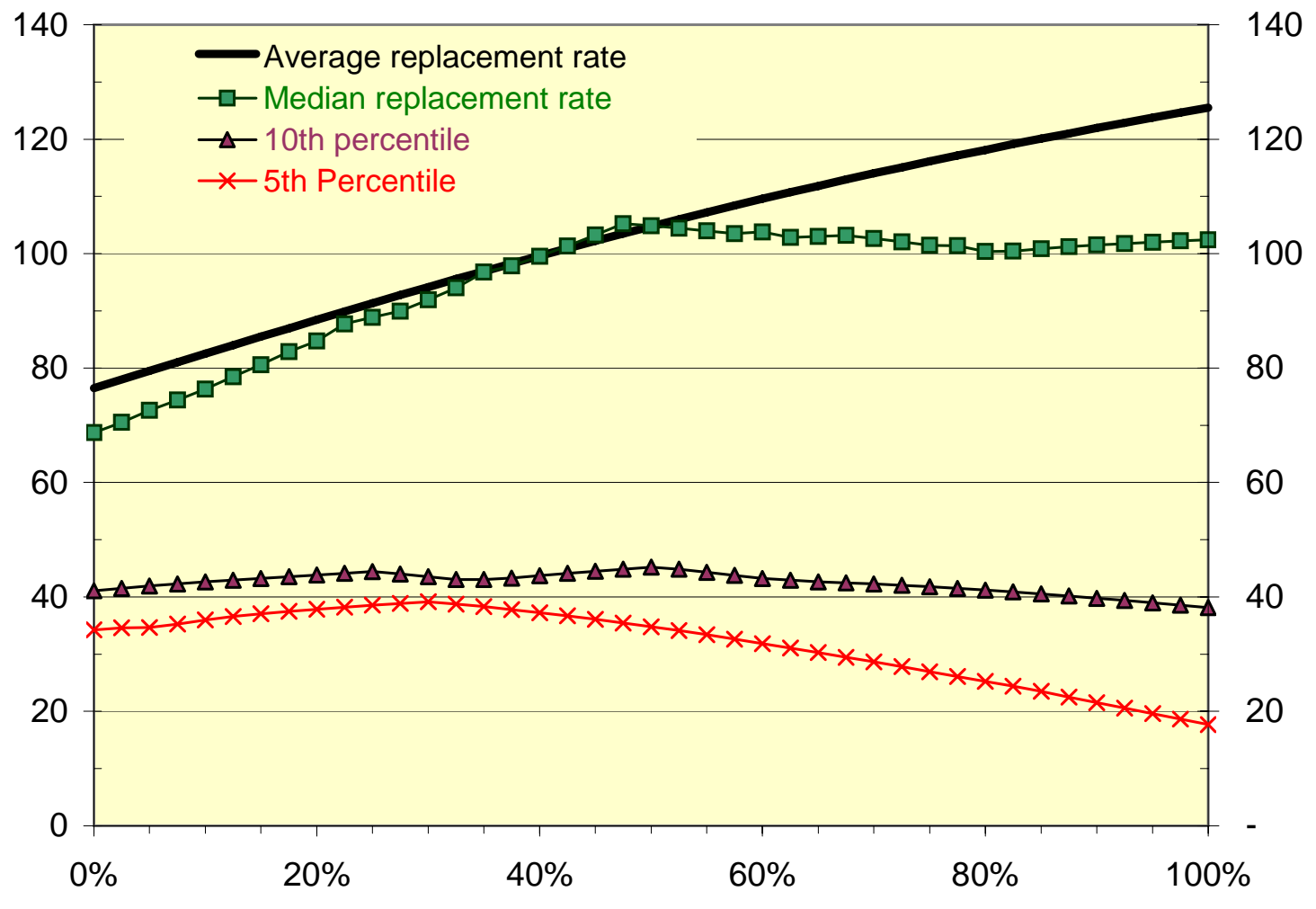

Allocation to foreign stocks (\% of total portfolio)

Source: Author's tabulations of annual composite stock and bond return data for eight industrial countries, 1927-2005, as explained in the text. Data supplied by Global Financial Data (http://www.globalfinancialdata.com). 
Figure 5. Replacement Rates of Full-Career U.S. Workers after Steady Investment in Alternative Portfolios Allocated across Eight Industrial Countries, 1927-2005
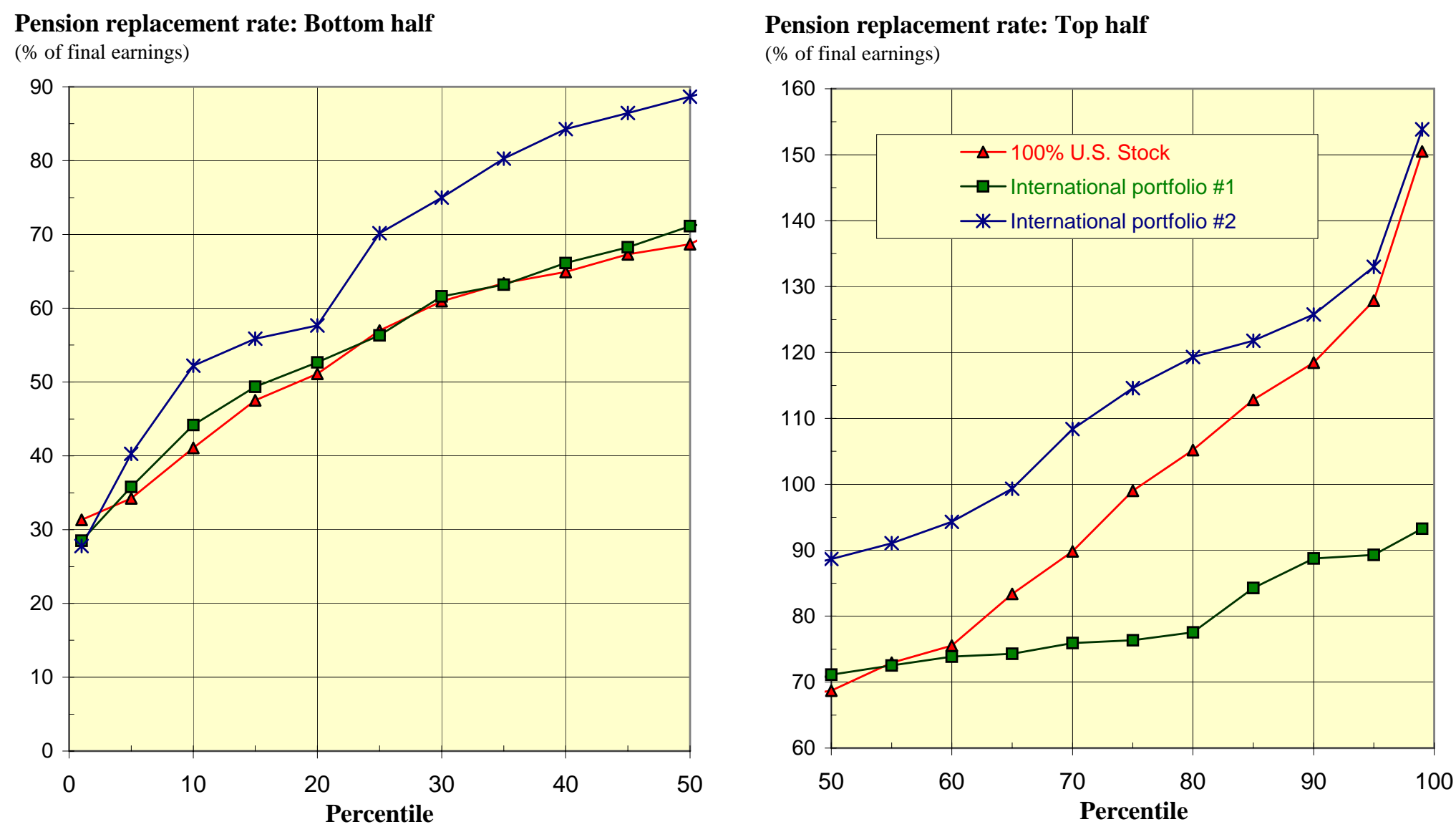

Source: Author's tabulations based on annual composite stock and bond return data from eight industrial countries, 1927-2005, as explained in the text. Allocation to each foreign country's asset is determined by stochasitic optimization. Return and foreign exchange data supplied by Global Financial Data (http://www.globalfinancialdata.com). 


\section{RECENT WORKING PAPERS FROM THE}

\section{CENTER FOR RETIREMENT RESEARCH AT BOSTON COLLEGE}

State Age Protection Laws and the Age Discrimination in Employment Act Joanna Lahey, November 2006

Age, Women, and Hiring: An Experimental Study

Joanna Lahey, November 2006

Optimal Retirement Asset Decumulation Strategies: The Impact of Housing Wealth Anthony Webb, Robert Triest, and Wei Sun, November 2006

The Impact of Aggregate Mortality Rise on Defined Benefit Pension Plans Irena Dushi, Leora Friedberg, and Anthony Webb, November 2006

Health Care Costs, Taxes, and the Retirement Decision: Conceptual Issues and Illustrative Simulations

Rudolph G. Penner and Richard W. Johnson, November 2006

Why Do Boomers Plan to Work So Long?

Gordon B.T. Mermin, Richard W. Johnson, and Dan Murphy, November 2006

Job Tenure and Pension Coverage

Alicia H. Munnell, Kelly Haverstick, and Geoffrey Sanzenbacher, October 2006

Has the Displacement of Older Workers Increased?

Alicia H. Munnell, Steven Sass, Mauricio Soto, and Natalia Zhivan, September 2006

No Place Like Home: Older Adults and their Housing

Timothy Smeeding, Barbara Boyle Torrey, Jonathan Fisher, David S. Johnson, and Joseph Marchand, August 2006

Effects of Public Policies on the Disposition of Lump-Sum Distributions: Rational and Behavioral Influences

William G. Gale and Michael Dworsky, August 2006

Pensions, Social Security, Wealth and Lifetime Earnings: Evidence from the Health and Retirement Study

William G. Gale and John W.R. Phillips, August 2006

All working papers are available on the Center for Retirement Research website (http://www.bc.edu/crr) and can be requested by e-mail (crr@bc.edu) or phone (617-552-1762). 